Regular Research Article

\title{
Cultural Landscapes in the Asia-Pacific: Re-focusing UNESCO Designation on Community Participation
}

\author{
Wiwik Dharmiasih ${ }^{1 *}$ \\ 1 Universitas Udayana; \\ * Corresponding author: wiwikd@unud.ac.id
}

\begin{abstract}
World Heritage Sites, designated by UNESCO, are a growing phenomenon in global governance. Sites are nominated for their Outstanding Universal Values with the objective of protecting against potential threats from man-made or natural causes. This article focuses on one type of recognition, the Cultural Landscape, which is unique because it is a living heritage site. Within Cultural Landscapes, people continue to carry out their lives and livelihoods as part of the site. The aim of this article is to examine the way community participation takes place in the designation of Cultural Landscapes. Findings highlight some ideas for researchers and policymakers to re-examine blind spots relative to community participation and offer some considerations for more meaningfully engaging local voices, particularly with respect to vulnerable populations and generational transition. Overall, research on Cultural Landscapes need not only examine what is being protected, but also must explore the new institutions being established, which can transform sites from within.
\end{abstract}

Keywords: UNESCO; Cultural Landscape; World Heritage Site; Community participation; Socio-ecological systems

\section{Introduction: UNESCO, Cultural Landscapes, and Community Participation}

The idea for protecting world heritage sites began after World War I, and gained international traction in the late 1950 s and 60 s due to development projects threatening historical and archaeological sites. As sites began to increase in number, UNESCO's World Heritage Convention in 1972 established a new set of rules on the identification, protection, and preservation of natural and cultural heritage (Jimura, 2019). Hence, UNESCO created a set of protocols for identifying Outstanding Universal Values (OUV), which forms the basis for designating a World Heritage Site. As of May 2020 there are a total of 1,121 properties listed around the world (UNESCOa, 2020). These properties are further divided into various categories, which include 869 cultural, 213 natural, and 39 mixed cultural-natural sites. Cultural heritage sites are the most commonly known, which include monuments, groups of buildings, and other major landmarks (listed as Article 1); while natural heritage sites focus on the physical, biological, or geological formations or clusters (Article 2) (UNESCOb, 2020). The Asia-Pacific region has close to one quarter of these sites, amounting to a total of 268, divided between 189 cultural sites, 67 natural sites, and 12 mixed sites.

The selection and designation of World Heritage Sites has also come to represent ideals of global cooperation, introducing new governance mechanisms between international institutions and between states, as well as establishing new ideals about what type of sites should be protected and promoted (Meskell, 2018). Numerous approaches to researching World Heritage Sites have also emerged, ranging from research on international regimes (Schmitt, 2009; Zacharias, 2010), the politics of inscription (Di Giovine, 2008; Bertacchini and Saccone, 2012; Wardana, 2019), ways of defining heritage (Taylor, 2012), planning and management challenges (Hall and McArthur, 1997; Landorf, 2009), conflict and trans-boundary issues (Albrecht, 2010; Young and Goldman, 2015; Svels and Sande, 2016), tourism (both normative, e.g. Wager, 1995; and critical tourism studies, e.g. MacRae, 2017), development (Hampton, 2005), site specific and regional studies (see for example, Logan, 2014 on Asia) and many others. 
Table 1. Cultural Landscapes in the Asia-Pacific by Country

\begin{tabular}{|c|c|}
\hline Country & Cultural Landscape \\
\hline Afghanistan & - Cultural Landscape and Archaeological Remains of the Bamiyan Valley \\
\hline Australia & $\begin{array}{l}\text { - Uluru-Kata Tjuta National Park } 1 \\
\text { - Budj Bim Cultural Landscape }\end{array}$ \\
\hline Azerbaijan & - Gobustan Rock Art Cultural Landscape \\
\hline China & $\begin{array}{l}\text { - Lushan National Park } \\
\text { - Mount Wutai } \\
\text { - West Lake Cultural Landscape of Hangzhou } \\
\text { - Cultural Landscape of Honghe Hani Rice Terraces } \\
\text { - Zuojiang Huashan Rock Art Cultural Landscape }\end{array}$ \\
\hline India & - Rock Shelters of Bhimbetka \\
\hline Indonesia & $\begin{array}{l}\text { - Cultural Landscape of Bali Province: the Subak System as a Manifestation of } \\
\text { the Tri Hita Karana Philosophy }\end{array}$ \\
\hline Iran (Islamic Republic of) & $\begin{array}{l}\text { - Bam and its Cultural Landscape } \\
\text { - The Persian Garden } \\
\text { - Cultural Landscape of Maymand }\end{array}$ \\
\hline Israel* & - Incense Route - Desert Cities in the Negev \\
\hline Japan & $\begin{array}{l}\text { - Sacred Sites and Pilgrimage Routes in the Kii Mountain Range } \\
\text { - Iwami Ginzan Silver Mine and its Cultural Landscape }\end{array}$ \\
\hline Kazakhstan & - Petroglyphs within the Archaeological Landscape of Tamgaly \\
\hline Kyrgyzstan & - Sulaiman-Too Sacred Mountain \\
\hline Lao People's Democratic Republic & $\begin{array}{l}\text { - Vat Phou and Associated Ancient Settlements within the Champasak Cultural } \\
\text { Landscape }\end{array}$ \\
\hline Lebanon & $\begin{array}{l}\text { - Ouadi Qadisha (the Holy Valley) and the Forest of the Cedars of God (Horsh } \\
\text { Arz el-Rab) }\end{array}$ \\
\hline Mongolia & - Orkhon Valley Cultural Landscape \\
\hline New Zealand & - Tongariro National Park \\
\hline Palestine & $\begin{array}{l}\text { - Palestine: Land of Olives and Vines - Cultural Landscape of Southern } \\
\text { Jerusalem, Battir }\end{array}$ \\
\hline Papua New Guinea & - Kuk Early Agricultural Site \\
\hline Philippines & - Rice Terraces of the Philippine Cordilleras \\
\hline Singapore & - Singapore Botanic Gardens \\
\hline Syrian Arab Republic & - Ancient Villages of Northern Syria \\
\hline United States *(Pacific Islands) & - Papahānaumokuākea \\
\hline Vanuatu & - Chief Roi Mata's Domain \\
\hline Vietnam & - Trang An Landscape Complex \\
\hline
\end{tabular}

*left UNESCO in 2019. Source: UNESCOe (2020)

Several studies also specifically consider how designation interacts with local concerns, influencing local cultures, economies, and ecologies. With state intervention and the arrival of tourism that often accompanies listing as a World Heritage Site, many serve to gain, while for others, designation can dramatically change the lives and livelihoods of people from within and surrounding the site in unexpected ways. Studies focusing on the local impacts have been done through surveying local perceptions about sites (Nicholas et al., 2009), exploring values between stakeholders, such as designation perceptions between locals, officials, and tourists (Black and Wall, 2001), while others conduct participatory or ethnographic approaches, examining how designation is experienced among local communities (e.g. Acabado, 2012).

This article focuses on a specific type of World Heritage Site that are particularly sensitive to local changes, the Cultural Landscape. A category established by UNESCO in 1992, Cultural Landscapes "express a long and intimate relationship between peoples and their natural environment ... often reflect[ing] specific techniques of sustainable land use, considering the characteristics and limits of the natural environment they are established in, and a specific spiritual 
relation to nature" (UNESCOc, 2020). To date there are 114 of these sites worldwide and according to Ken Taylor (2012: 34) "they are a vivid embodiment of landscape as cultural process as opposed to being an objective cultural product." This notion of Cultural Landscape that Taylor describes (ibid: 31), is rooted in Asia, as opposed to more Western articulations of the Landscape, and furthermore has redefined the ways that World Heritage Sites are identified and designated. For this reason, the scope of this article is limited to the Asia-Pacific region, on sites designated as Cultural Landscapes, whereby culture and nature are closely interlinked. My research is also rooted more specifically in examples from Southeast Asia.

Table 1 lists Cultural Landscapes from the Asia-Pacific region. These sites have been shaped by dynamic political economies that produce unique landscapes and are promoted for World Heritage status as a way to protect against threats, to recognize a particular cultural value, or to generate additional income. Designation can dramatically alter a site due to the influx of visitors and new institutional structures to manage landscapes. This paper therefore serves as a call to go beyond issues of protection and management of the site to better understand how the local cultural institutions and ecologies are changing. In short, how do we learn to better listen to the local voices in and around these sites? The importance of listening to local voices might seem unusual given that sites are intended to support local cultural institutions. Nevertheless, given that states are responsible for designating and administering sites through formal government agencies, it is especially important to ensure that local decision-making processes are not undermined or overlooked (Yasuda, 2010; Meskell, 2018). The aim of this article is therefore to examine community participation in the designation of Cultural landscapes in the Asia Pacific and provide more explicit theoretical, methodological, and conceptual engagement centered around voices of local communities.

In the ensuing sections I first describe my research and the overall empirical material for this article. Second, I turn to processes of participation relative to designation, examining dynamics across the lengthy procedures for establishing sites as Cultural Landscapes. Third, I highlight some principles for continuing to focus on meaningful participation, and furthermore, point to areas often overlooked, namely those related to vulnerable populations and the way that heritage is passed down to future generations.

\section{Researching UNESCO and Cultural Landscapes}

I began getting exposed to research on UNESCO World Heritage Sites in 2010, when I was invited to participate in the nomination dossier process for the Cultural Landscape of Bali province. At that time, I served as an observer, providing research and input on the revisions of chapter 5 of the dossier, specific to the management plan (Lansing and Dharmiasih, 2012). Since then, and beyond designation in 2012, I have remained closely involved in working on issues related to the site. My focus as an academic throughout, is rooted in conducting research with local people and cultural institutions (Pedersen and Dharmiasih, 2015; Royo et al., 2016; Dharmiasih and Arbi, 2017; Dharmiasih and Arbi, 2018; Dharmiasih, 2019). Through this engagement I also began working with a network of advocates from Southeast Asia, conducting cross visits and attending workshops in Thailand, Vietnam, and Malaysia. In 2015, I joined the World Heritage Watch network, a civil society organization that functions as a watchdog for accountability. As a result, I was invited to join international observation summits in Germany, Istanbul, and Poland. I was also granted access as a civil society representative to observe the 2018 UNESCO convention in Poland.

Through my research I noticed tensions across different governing scales, between an international governing body like UNESCO, as well as the interests of states, various subnational entities, and local communities. I also noticed that these tensions emerged as part of administrative issues, whereby local and usually non-formalized cultural institutions are undermined in the designation of Cultural Landscapes. Various changes occur with designation at these sites, as new 
management structures are established. As Yasuda (2010) has also shown in the Japanese context, the symbolic cultural values might also become an arena of contestation among formal elites. The Cultural Landscape of Bali Province, where I have conducted most of my research, indicates that although management encourages community empowerment (a bottom-up approach), the proposed structure of the Governing Assembly reflected a top-down approach for site management (Dharmiasih and Arbi, 2018). Civil society initiatives sought to reorient the process back towards community voices (Royo et al., 2016), drafting multi-stakeholder discussions for sustainable tourism studies (Dharmiasih and Arbi, 2017) through trusted local leaders, but over time the management interests change. Indeed, site management today is largely driven by tourism interests, and there is fierce competition over controlling the benefits that come alongside a visitor industry (Dharmiasih, 2019). It is these observations that led me to further examine ways to listen to and hear community voices at Cultural Landscapes.

\section{Local community participation in the nomination of Cultural Landscapes}

Sites nominated for World Heritage are almost always selected by outside actors, which include experts, state representatives, and other professionals (Leask and Fyall, 2006). They are the ones who interpret the values that meet criteria for inscription, as well as mapping out the sites (core and buffer zones), documenting the preparation process, and establishing the management system for the site. The values of the site are often simplified into a symbolic ideal to meet the criteria for inscription, whereas there might be regional variations, multiple interpretations, and other complexities. However, the subsequent management plan established for the site is redefined through these newly introduced values, reshaping meanings elsewhere (e.g. Roth and Sedana, 2015). This poses a unique challenge for participation, which may set out to protect something at risk but can end up imposing a new set of values that might not necessarily be a priority for local communities, a process that is consistent with Meskell's (2018) notion of erasure of indigenous values.

Community participation during the nomination process is usually limited to getting approval and is negotiated between external actors and local key stakeholders at the site (Royo et al., 2015). The broader community is most often left out, so formal state representatives decide among themselves (e.g. Yasuda, 2010; Dharmiasih and Arbi, 2016). This also means that the decision making powers shift away from local people and local governing processes, even if UNESCO's stated intent is to protect the community from threats and empower development (Chirikure et al., 2010). In some cases, locals question the demarcation of the site. At my research site in Bali for example, people often question the basis for choosing the boundaries of the Cultural Landscape, given that the subak is a cultural institution across all of Bali.

Given that the overarching goal is nomination, implementing activities in the management plan becomes less of a priority. Governing bodies tend to assume that management responsibilities shift to local communities, but without the allocation of resources to carry out these activities, local cultural institutions experience difficulties in carrying out the additional responsibilities (Dharmiasih and Arbi, 2018). Furthermore, local cultural institutions also experience diminishing authority to be able to call attention to an issue because administration has shifted to formal institutions, or worse, new institutions are established that undermine the longstanding cultural institutions (Dharmiasih, 2019).

Hall and McArthur (1997: 21) describes the role of tourism as follows: "Listing is meant to bring in extra tourists to the site or attract more government and agency support for the maintenance of the site's values...potentially chang[ing] access and use of the site, [establishing] new regulatory structures, and chang[ing] economic flows... [as well as] the politics of heritage and even who visits." Designation as a World Heritage Site almost always experiences an uptick in tourism. Indeed, this is an intended consequence of nomination. Over time, however, tourism growth can become a central 
driver of the local economy, outfitted to attract more visitors that can on the one hand prove unsustainable, and on the other hand, becomes a problem if tourism interests begin to supersede local cultural values and institutions.

\section{Rethinking participation at Cultural Landscapes}

There is a rich literature on participation in socio-ecological systems, which are a core focus of theories and approaches in adaptive co-management and community-centered conservation (Armitage et al., 2010; Armitage et al., 2020). Experts that lead World Heritage nomination processes incorporate these concepts into management plans. However, implementing mechanisms for participation in complex socio-ecological systems are rooted in trust, reciprocity, and cooperation (Ostrom, 1990), principles that do not get adequate attention in Cultural Landscape planning, management, and monitoring (Royo et al., 2016).

The overwhelming focus on nomination is driven by administrative requirements and not enough attention is devoted to the institutions for continued participation. Particularly as Cultural Landscapes target sensitive human-nature relations, inadequate participation can disrupt local livelihoods and reshape landscapes. In Jatiluwih, for example, the rapid increase in number of visitors without adequate local facilitation has resulted in local conflicts about the future development of the site, which threaten the intended values of nomination by changing land uses, disrupting and polluting irrigation systems, and directly undermining local farmers (Dharmiasih, 2020). Such outcomes can be better anticipated and potentially avoided through more explicit focus on bottom-up approaches that are more flexible and in line with the values of a dynamic living heritage (see for example Acabado et al., 2014 on participatory archaeology). Furthermore, emphasizing the locally rooted management approaches can help demand upward accountability mechanisms, assisting cultural institutions to thrive and innovate pathways for managing the site based on local values rather than outside interests. Nevertheless, UNESCO designation is driven by potential tourism development, and although nomination processes include mitigation plans for addressing tourism, there needs to be more explicit ways for acknowledging and upholding local values of sustainability to avoid rapid developments that threaten the integrity of sites.

Issues of participation in UNESCO designation and the influence of tourism also highlights the key question of who benefits. Although broader issues of community participation require attention, there are two specific I would like to highlight, which are often overlooked in the study of Cultural Landscapes, namely issues related to vulnerable populations, and a focus on generational transition.

\subsection{Focusing on vulnerable people}

There are many levels of participation (Arnstein, 1969) and at World Heritage Sites Chirikure et al. (2010: 30) has convincingly shown that "Communities are neither universal nor homogenous." In the nomination process, a person considered the leader of the community is usually appointed to get input from community members. Sometimes there are community factions, and in other instances the message does not reach the broader community. Such appointed leaders also have their own understanding and interpretations of the issues, and may also have their own interests. Although it is expected that the leader will convey the message and meaningfully discuss with other members, this does not always happen (Taylor, 2012).

Much of the research on participation at Cultural Landscapes has examined the relationship between UNESCO, the state, and the community writ large. However, less research is directed at the intra-community dynamics, specifically the actors and institutions that represent them (Agrawal and Gibson, 1999). The nomination process assigns vulnerability to the overall site and makes the case for protecting the community from potential threats. However, there are likely other power 
dynamics taking place within the community that involve existing vulnerabilities. For example, my ongoing research in Jatiluwih provided cameras to local farmers from various background to tell their stories about the subak and UNESCO designation. The women participants highlighted the unequal gendered labor relations in the subak, as well as the barriers for them to voice concerns to formal institution. Nomination can exacerbate these vulnerabilities or create new ones. Cultural Landscape research must more explicitly identify impacts to households and access to resource and decision-making processes, the role of women, and youth.

\subsection{Inheriting heritage: Generational transfer and youth}

The involvement of youth is especially important at Cultural Landscape. UNESCO and state parties have tried to engage young people through educational programs, inviting people from across the world and across regions to learn about sites. On the website UNESCO describes their youth initiatives, which include a World Heritage Youth Forum and World Heritage Young Professional Forum as "a chance to meet young people from other countries, learn about their heritage, discuss common concerns, and discover new roles for themselves in heritage conservation" (UNESCOd, 2020). The program shows UNESCO's awareness about the importance of youth, building networks and leadership, and promoting skills about heritage management. However, these programs are focused on policy dimensions of site management, bureaucratic processes, and regulatory issues, rather than the everyday transfer of knowledge that shape the landscapes across generations. Indeed, Meskell (2015) has gone as far as to describe UNESCO's programming in this light, as "transactional" for its own political purposes.

At sites that are unique for their agricultural practices, tourism development outweighs incentives to continue working as farmers. At my research site in Jatiluwih, even before designation, working as a farmer was considered dirty, challenging, and the results does not equal the effort. Older generations have long encouraged younger ones to get out of farming. Although aging farmers in Jatiluwih may be proud of their World Heritage status and their role in the subak, many still assign shame to farming as a livelihood and profession. One of the largest threats to sustainability so commonly overlooked is generational transition, whereby an older generation is eager to pass down its traditions, and a younger one is willing to accept them. For researchers studying Cultural Landscapes, generational change has not received much attention, raising questions about who will continue to manage the landscape. I believe a concerted research agenda devoted to the future guardians of heritage is long overdue. Indeed, the questions of generational transition is not limited to Cultural Landscapes and is part of larger questions about smallholders, agriculture, and the future of rural space (Rigg et al., 2020).

\section{Conclusion}

Focusing on community participation helps to identify the central paradox of UNESCO Cultural Landscape designation. Whereas a local socio-cultural system has thrived organically, and indeed because of its strong community relations, designation creates new formalized institutional approaches to administer the site from beyond the community. The additional factor of tourism creates new pressures at sites, at once providing opportunity for some, while excluding others. Among sites recognized for its agricultural systems, those most responsible for creating and managing the landscape are often the last to benefit. I have shown how studies on community participation should follow in the example of Chirikure et al. (2010), which remind us that communities are not monolithic (Agrawal and Gibson, 1999). Furthermore, among diverse and divergent perspectives in a community, studies need to focus greater attention on vulnerable populations, such as the case of gendered labor dimensions in the subak that I describe in this article. Finally, Acabado's (2012) work in the Rice Terraces of the Philippine Cordilleras uses archaeological approaches to show the dynamism of Cultural Landscapes over generations. He shows just how 
important it is to understand the local adaptations as a source of strength rather than seeing the Ifugao as a static cultural system. My research site in Jatiluwih is undergoing a reckoning over the generational transition unfolding there. Future questions need to ask how designation is situated within local dimensions of generational change, and to what ends?

In this article, I reflected on the various research initiatives I have been part of to better understand and assist in community participation at the Cultural Landscape of Bali Province. Upon the establishment of a top down general assembly, we facilitated forums to bring subak leaders together, conducting participatory mapping, and working across multi-stakeholder groups to draft a sustainable tourism strategy. More recently, applying a photovoice methodology by providing cameras across different generations of local residents in Jatiluwih, we are encouraging local perspectives to share their experience about change and designation. There are many opportunities to continue to innovate methodological approaches for eliciting local voices that connect with decisionmakers administering the site. Tools among researchers to engage on community participation can have significant outcomes in approaching nomination or monitoring designated sites. Such innovations to improve participation can help to address the instrumental bureaucratic processes that currently drive nomination by introducing upward accountability that respond to local priorities from designation.

\section{Conflicts of interest}

Author declares no conflict of interest.

\section{References}

Acabado, S. B. (2012). Taro before rice terraces: implications of radiocarbon determinations, ethnohistoric reconstructions, and ethnography in dating the Ifugao terraces. Senri ethnological studies, 78, 285-305. doi: http://doi.org/10.15021/00002522

Acabado, S., Martin, M., \& Lauer, A. J. (2014). Rethinking History, Conserving Heritage. SAA Archaeological Record.

Agrawal, A., \& Gibson, C. C. (1999). Enchantment and disenchantment: the role of community in natural resource conservation. World development, 27(4), 629-649. doi: https://doi.org/10.1016/S0305-750X(98)00161-2

Albrecht, M. (2010). Transboundary governance of the Curonian spit world heritage site. Journal of Environmental Planning and Management,53(6), 725-742. doi: https://doi.org/10.1080/09640568.2010.488105

Armitage, D., Berkes, F., \& Doubleday, N. (Eds.). (2010). Adaptive co-management: collaboration, learning, and multi-level governance. UBC Press.

Armitage, D., Mbatha, P., Muhl, E. K., Rice, W., \& Sowman, M. (2020). Governance principles for community-centered conservation in the post-2020 global biodiversity framework. Conservation Science and Practice, 2(2), e160. doi: https://doi.org/10.1111/csp2.160

Arnstein, S. (1969). "A Ladder of Citizen Participation": Journal of the American Institute of Planners. pp 216-24.

Bertacchini, E. E., and Donatella, S. (2012). Toward a Political Economy of World Heritage. Journal of Cultural Economics, 36(4), 327-52.

Black, H., \& Wall, G. (2001). Global-local inter-relationships in UNESCO world heritage sites. Interconnected Worlds. Tourism in Southeast Asia, Amsterdam, Pergamon, 121-136.

Chirikure, S., Manyanga, M., Ndoro, W., \& Pwiti, G. (2010). Unfulfilled promises? Heritage management and community participation at some of Africa's cultural heritage sites. International Journal of Heritage Studies, 16(1-2), 30-44. doi: https://doi.org/10.1080/13527250903441739 
Di Giovine, M. A. (2008). The heritage-scape: UNESCO, world heritage, and tourism. Lexington Books.

Ferrucci, S. (2012). UNESCO's World Heritage regime and its international influence. tredition.

Hall, C. M., \& McArthur, S. (1997). Integrated heritage management. John Wiley \& Sons.

Hampton, M. P. (2005). Heritage, local communities and economic development. Annals of tourism Research, 32(3), 735-759. doi: https://doi.org/10.1016/j.annals.2004.10.010

Jimura, T. (2018). World Heritage Sites: Tourism, local communities and conservation activities. CABI.

Landorf, C. (2009). Managing for sustainable tourism: a review of six cultural World Heritage Sites. Journal of Sustainable Tourism, 17(1), 53-70. doi: https://doi.org/10.1080/09669580802159719

Dharmiasih, W. (2019). Management in Question at The Cultural Landscape of Bali Province. World Heritage Watch, pp 79-82

Dharmiasih, W. (2020). Community Perspectives on State - UNESCO Management of Bali's World Heritage Site. World Heritage Watch, pp $110-113$

Dharmiasih, W. and Arbi, Y. (2016). Empowering the Local Community for the Management of the Subak Landscape of Bali. World Heritage Watch, pp 147-149

Dharmiasih, W. and Arbi, Y. (2017). Growing Pains of the Cultural Landscape of Bali: Key Priorities Towards Sustainable Tourism. World Heritage Watch, 92-94

Dharmiasih, W. and Arbi, Y. (2018). Management of the Cultural Landscape of Bali Province in Fitsand-Starts. World Heritage Watch, pp 108-110

Lansing, S., and Dharmiasih, W. (2014). Can World Heritage Status Save Bali from Destruction? Strategic Review-Indonesia, 360.

Logan, W. (2012). States, Governance and the Politics of Culture: World Heritage in Asia. Routledge Handbook of Heritage in Asia, pp 113-28.

MacRae, G. (2017). Universal heritage meets local livelihoods: 'awkward engagements' at the world cultural heritage listing in Bali. International journal of heritage studies, 23(9), 846-859. doi: https://www.tandfonline.com/doi/abs/10.1080/13527258.2017.1339107

Meskell, L (2018). A Future in Ruins: UNESCO, World Heritage, and the Dream of Peace. Oxford University Press, 2018.

Meskell, L. (2015). Transacting UNESCO World Heritage: gifts and exchanges on a global stage. Social Anthropology, 23(1), 3-21. doi: https://doi.org/10.1111/1469-8676.12100

Nicholas, L. N., Thapa, B., \& Ko, Y. J. (2009). Residents' Perspectives of a World Heritage Site: The Pitons Management Area, St. Lucia. Annals of tourism research, 36(3), 390-412. doi: https://doi.org/10.1016/j.annals.2009.03.005

Pedersen, L., \& Dharmiasih, W. (2015). The enchantment of agriculture: State decentering and irrigated rice production in Bali. The Asia Pacific Journal of Anthropology, 16(2), 141-156. doi: https://doi.org/10.1080/14442213.2014.992458

Rigg, J., Phongsiri, M., Promphakping, B., Salamanca, A., \& Sripun, M. (2020). Who will tend the farm? Interrogating the ageing Asian farmer. The Journal of Peasant Studies, 47(2), 306-325. doi: https://doi.org/10.1080/03066150.2019.1572605

Roth, D., \& Sedana, G. (2015). Reframing Tri Hita Karana: From 'Balinese Culture' to Politics. The Asia Pacific Journal of Anthropology, 16(2), 157-175. doi: https://doi.org/10.1080/14442213.2014.994674

Royo, A., Dharmiasih, W., \& Arbi, Y. (2016). Forum Pekaseh in the Management of Subak Landscape of Catur Angga Batukaru, UNESCO World Heritage Sites in Bali. In Asian Sacred Natural Sites (pp. 140-152). Routledge.

Schmitt, T. M. (2009). Global cultural governance. decision-making concerning World Heritage between politics and science. Erdkunde, 103-121. 
Svels, K., \& Sande, A. (2016). Solving landscape-related conflicts through transnational learning? The case of transboundary Nordic World Heritage sites. Landscape Research, 41(5), 524-537. doi: https://doi.org/10.1080/01426397.2016.1151485

Taylor, K. (2009). Cultural landscapes and Asia: reconciling international and Southeast Asian regional values. Landscape research, 34(1), 7-31. doi: https://doi.org/10.1080/01426390802387513

Taylor, K. (2012). Landscape and meaning: Context for a global discourse on cultural landscape values. In Managing cultural landscapes. Routledge, Taylor \& Francis Group.

UNESCOa. (2020). UNESCO World Heritage Centre - World Heritage List." UNESCO World Heritage Centre. Accessed May 17, 2020. https://whc.unesco.org/en/list/.

UNESCOb. (2020). The Operational Guidelines for the Implementation of the World Heritage Convention. UNESCO World Heritage Centre. Accessed May 17, 2020. https://whc.unesco.org/en/guidelines/.

UNESCOc. (2020). Cultural Landscapes. UNESCO World Heritage Centre. Accessed May 17, 2020. https://whc.unesco.org/en/culturallandscape/.

UNESCOd. (2020). World Heritage Youth Forum. UNESCO World Heritage Centre. Accessed May 17, 2020. https://whc.unesco.org/en/youth-forum/.

UNESCOe. (2020). List of UNESCO Member States | United Nations Educational, Scientific and Cultural Organization. Accessed May 17, 2020. http://www.unesco.org/eri/cp/ListeMS_Indicators.asp.

Wager, J. (1995). Developing a strategy for the Angkor world heritage site. Tourism Management, 16(7), 515-523. doi: https://doi.org/10.1016/0261-5177(95)00069-Z

Wardana, A. (2020). Neoliberalizing cultural landscapes: Bali's agrarian heritage. Critical Asian Studies, 1-16. doi: https://doi.org/10.1080/14672715.2020.1714459

Yasuda, H. (2010). World heritage and cultural tourism in Japan. International Journal of Culture, Tourism and Hospitality Research. doi: https://doi.org/10.1108/17506181011081532

Young, H., \& Goldman, L. (Eds.). (2015). Livelihoods, natural resources, and post-conflict peacebuilding. Routledge.

Zacharias, D. (2010). The UNESCO regime for the protection of World Heritage as prototype of an autonomy-gaining international institution. In The exercise of public authority by international institutions (pp. 301-336). Springer, Berlin, Heidelberg. doi: https://doi.org/10.1007/978-3642-04531-8_11 